\title{
Front Matter: Volume 10047
}

, "Front Matter: Volume 10047," Proc. SPIE 10047, Optical Methods for Tumor Treatment and Detection: Mechanisms and Techniques in Photodynamic Therapy XXVI, 1004701 (12 April 2017); doi: 10.1117/12.2269858 


\title{
PROGRESS IN BIOMEDICAL OPTICS AND IMAGING

\section{Optical Methods for Tumor Treatment and Detection: Mechanisms and Techniques in Photodynamic Therapy XXVI}

\author{
David H. Kessel \\ Tayyaba Hasan \\ Editors
}

28-29 January 2017

San Francisco, California, United States

Sponsored and Published by

SPIE 
The papers included in this volume were part of the technical conference cited on the cover and title page. Papers were selected and subject to review by the editors and conference program committee. Some conference presentations may not be available for publication. The papers published in these proceedings reflect the work and thoughts of the authors and are published herein as submitted. The publisher is not responsible for the validity of the information or for any outcomes resulting from reliance thereon.

Please use the following format to cite material from these proceedings:

Author(s), "Title of Paper," in Optical Methods for Tumor Treatment and Detection: Mechanisms and Techniques in Photodynamic Therapy XXVI, edited by David H. Kessel, Tayyaba Hasan, Proceedings of SPIE Vol. 10047 (SPIE, Bellingham, WA, 2017) Seven-digit Article CID Number.

ISSN: 1605-7422

ISSN: 2410-9045 (electronic)

ISBN: 9781510605350

ISBN: 9781510605367 (electronic)

Published by

SPIE

P.O. Box 10, Bellingham, Washington 98227-0010 USA

Telephone +1 3606763290 (Pacific Time) · Fax +1 3606471445

SPIE.org

Copyright (C) 2017, Society of Photo-Optical Instrumentation Engineers.

Copying of material in this book for internal or personal use, or for the internal or personal use of specific clients, beyond the fair use provisions granted by the U.S. Copyright Law is authorized by SPIE subject to payment of copying fees. The Transactional Reporting Service base fee for this volume is $\$ 18.00$ per article (or portion thereof), which should be paid directly to the Copyright Clearance Center (CCC), 222 Rosewood Drive, Danvers, MA 01923. Payment may also be made electronically through CCC Online at copyright.com. Other copying for republication, resale, advertising or promotion, or any form of systematic or multiple reproduction of any material in this book is prohibited except with permission in writing from the publisher. The CCC fee code is 1605 $7422 / 17 / \$ 18.00$.

Printed in the United States of America.

Publication of record for individual papers is online in the SPIE Digital Library.

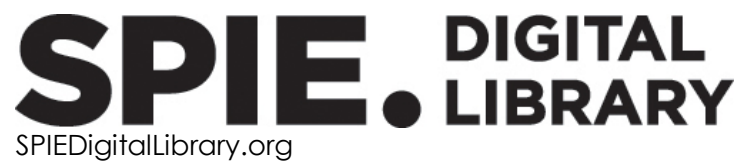

Paper Numbering: Proceedings of SPIE follow an e-First publication model, with papers published first online and then in print. Papers are published as they are submitted and meet publication criteria. A unique citation identifier (CID) number is assigned to each article at the time of the first publication. Utilization of CIDs allows articles to be fully citable as soon as they are published online, and connects the same identifier to all online, print, and electronic versions of the publication. SPIE uses a seven-digit CID article numbering system in which:

- The first five digits correspond to the SPIE volume number.

- The last two digits indicate publication order within the volume using a Base 36 numbering

system employing both numerals and letters. These two-number sets start with 00, 01, 02, 03, 04, $05,06,07,08,09,0 A, 0 B \ldots$. OZ, followed by 10-1Z, 20-2Z, etc.

The CID Number appears on each page of the manuscript. The complete citation is used on the first page, and an abbreviated version on subsequent pages. 


\title{
Contents
}

\author{
$\checkmark$ Authors \\ vii Conference Committee
}

\section{SESSION 1 PHOTODYNAMIC THERAPY I}

1004702 Sequential vs. simultaneous photokilling by mitochondrial and lysosomal photodamage (Invited Paper) [10047-1]

\section{SESSION 2 PHOTODYNAMIC THERAPY II}

1004707 In vivo wide-field multispectral dosimeter for use in ALA-PpIX based photodynamic therapy of skin [10047-5]

\section{SESSION 3 PHOTODYNAMIC THERAPY III}

10047 OA Oxygen measurements to improve singlet oxygen dosimetry [10047-9]

10047 OD Phototoxic effects of free phthalocyanine and phthalocyanine conjugated to gold nanoparticles for targeted photodynamic therapy of melanoma cancer [10047-13]

\section{SESSION 4 PHOTODYNAMIC THERAPY IV}

10047 OG A compact diode laser based all-fiber delivery system for PDT+PTT with integrated temperature sensing capabilities [10047-15]

\section{SESSION 5 PHOTODYNAMIC THERAPY V}

10047 OK Minimally toxic approach for treatment of cutaneous breast cancer metastases: capecitabine-enhanced photodynamic therapy [10047-19]

\section{SESSION 6 PHOTODYNAMIC THERAPY VI}

10047 OM Real time laser speckle imaging monitoring vascular targeted photodynamic therapy [10047-22]

10047 ON Intraoperative photodynamic treatment for high-grade gliomas [10047-23]

1004700 Invasion-promoting extracellular matrix composition enhances photodynamic therapy response in 3D pancreatic cancer models [10047-27] 
10047 OQ Multimodal OCT for assessment of vasculature-targeted PDT success [10047-25]

10047 OR Overview of computational simulations for PDT treatments based on optimal choice of singlet oxygen [10047-26]

10047 OS Simple and optimum background-free estimation method of PPIX fluorescence for 5-ALAbased fluorescence diagnosis of malignant lesions [10047-28]

\section{SESSION 8 PHOTODYNAMIC THERAPY VIII}

10047 OU Novel trace norm regularization method for fluorescence molecular tomography reconstruction [10047-30]

\section{POSTER SESSION}

10047 OX Singlet oxygen explicit dosimetry to predict long-term local tumor control for BPDmediated photodynamic therapy [10047-33]

10047 OY 3-compartment dynamic model of talaporfin sodium pharmacokinetics in silico [10047-34]

1004710 Singlet oxygen explicit dosimetry to predict local tumor control for HPPH-mediated photodynamic therapy [10047-36]

1004711 Singlet oxygen explicit dosimetry to predict long-term local tumor control for Photofrinmediated photodynamic therapy [10047-37]

1004712 The relevance of light diffusion profiles for interstitial PDT using light-diffusing optical fibers [10047-38]

1004713 Target-specific porphyrin-loaded hybrid nanoparticles to improve photodynamic therapy for cancer treatment [10047-39]

1004714 Photodynamic therapy in neurosurgery: a proof of concept of treatment planning system [10047-40]

1004716 Phototodynamic activity of zinc monocarboxyphenoxy phthalocyane (ZnMCPPc) conjugated to gold silver (AuAg) nanoparticles in melanoma cancer cells [10047-42]

1004717 Four-channel PDT dose dosimetry for pleural photodynamic therapy [10047-43]

1004718 Temperature mapping and thermal dose calculation in combined radiation therapy and 13.56 $\mathrm{MHz}$ radiofrequency hyperthermia for tumor treatment [10047-44] 


\section{Authors}

Numbers in the index correspond to the last two digits of the seven-digit citation identifier (CID) article numbering system used in Proceedings of SPIE. The first five digits reflect the volume number. Base 36 numbering is employed for the last two digits and indicates the order of articles within the volume. Numbers start with 00, 01, 02, 03, 04, 05, 06, 07, 08, 09, OA, OB...0Z, followed by 10-12, 20-2Z, etc.

An, Yu, OU

Anand, Sanjay, OK

Arai, Tsunenori, OY

Bagnato, Vanderlei S., 12

Beeson, Karl, OR

Bullock, Taylor, OK

Celli, Jonathan P., 00

Cengel, Keith A., 17

Chi, Chongwei, OU

Cramer, Gwendolyn M., 00

Davis, Scott C., 07

Deleporte, P., ON

de Souza, Ana Luiza Ribeiro, 07

Dimofte, Andreea, 17

Dupont, C., ON, 14

El-Hamidi, Hamid, 00

Fenoglio, Ivana, OG

Finlay, Jarod C., OA, 17

Fortunato, Thereza C., 12

Gassino, Riccardo, OG

Gladkova, Natalia D., OQ

Goldschmidt, Ruth, OM

Gubarkova, Ekaterina V., OQ

Harada, Yoshinori, OS

He, Kunshan, OU

Imai, Kentaro, OY

Jiang, Shixin, OU

Kato, Yoshiyuki, OS

Kessel, David, 02

Kim, Jung Kyung, 18

Kim, Michele M., OA, OX, 10, 11, 17

Kim, Suzy, 18

Kirillin, Mikhail Y., OQ

Kiseleva, Elena B., $0 Q$

Kokalari, Ida, OG

Kurachi, Cristina, 12

Kuznetsov, Sergey S., OQ

LaRochelle, Ethan P. M., 07

Liu, Jie, OU

Liu, Yuhao, OU

Maehara, Sachio, OY

Malabi, Rudzani, OD, 16

Manoto, Sello Lebohang, OD, 16

Mao, Yamin, OU

Maphanga, Charles, OD, 16

Matsuo, Hisataka, OS

Matveev, Lev A., $0 Q$

Matveyev, Alexander L., $0 Q$

Maytin, Edward V., OK

\author{
Minamikawa, Takeo, OS \\ Mordon, S., ON, 14 \\ Moriyama, Lilian T., 12 \\ Mthunzi-Kufa, Patience, OD, 16 \\ Nyokong, Tebello, OD, 16 \\ Ogawa, Emiyu, OY \\ Ohtani, Keishi, OY \\ Oluwole, David Oluyinka, OD, 16 \\ Ombinda-Lemboumba, Saturnin, OD, 16 \\ Ong, Yi Hong, OA, OX, 10, 11, 17 \\ Ono, Shotaro, OY \\ Otsuji, Eigo, OS \\ Parilov, Evgueni, OR \\ Penjweini, Rozhin, 0A, 0X, 10, 11 \\ Perrone, Guido, OG \\ Pogue, Brian W., 07 \\ Potasek, Mary, OR \\ Prasad, Bibin, 18 \\ Reyns, N., 0N, 14 \\ Scherz, Avigdor, OM \\ Sirotkina, Marina A., OQ \\ Sovetsky, Alexander A., $0 Q$ \\ Stringasci, Mirian D., 12 \\ Takamatsu, Tetsuro, OS \\ Tanaka, Hideo, OS \\ Tian, Jie, OU \\ Uno, Yuko, OY \\ Usuda, Jitsuo, OY \\ Vallan, Alberto, $0 G$ \\ Vega, Daniel L., 13 \\ Vermandel, M., ON, 14 \\ Vitkin, Alex, $0 Q$ \\ Vivero-Escoto, Juan L., 13 \\ Vollet Filho, José Dirceu, 12 \\ Vyacheslav, Kalchenko, OM \\ Yanagisawa, Akio, OS \\ Ye, Jinzuo, OU \\ Zagaynova, Elena $\vee ., O Q$ \\ Zaitsev, Vladimir Y., $O Q$ \\ Zhang, Guanglei, OU \\ Zhu, Timothy C., OA, OX, 10, 11, 17
}


Proc. of SPIE Vol. 10047 1004701-6

Downloaded From: https://www.spiedigitallibrary.org/conference-proceedings-of-spie on 26 Apr 2023 Terms of Use: https://www.spiedigitallibrary.org/terms-of-use 


\title{
Conference Committee
}

\author{
Symposium Chairs \\ James G. Fujimoto, Massachusetts Institute of Technology \\ (United States) \\ R. Rox Anderson, Wellman Center for Photomedicine, Massachusetts \\ General Hospital (United States) and Harvard School of Medicine \\ (United States)
}

Program Track Chair:

Brian Jet-Fei Wong, Beckman Laser Institute and Medical Clinic (United States)

Conference Chairs

David H. Kessel, Wayne State University (United States)

Tayyaba Hasan, Massachusetts General Hospital (United States)

Conference Program Committee

Imran Rizvi, Wellman Center for Photomedicine (United States)

Jonathan P. Celli, University of Massachusetts Boston (United States)

Session Chairs

1 Photodynamic Therapy I

David H. Kessel, Wayne State University School of Medicine (United States)

2 Photodynamic Therapy II

Tayyaba Hasan, Wellman Center for Photomedicine (United States)

Richard W. Davis, Perelman Center for Advanced Medicine

(United States)

3 Photodynamic Therapy III

Theresa Busch, University of Pennsylvania (United States)

4 Photodynamic Therapy IV

Imran Rizvi, Wellman Center for Photomedicine (United States)

Wenbin Lin, The University of Chicago (United States) 
5 Photodynamic Therapy $\vee$

Keith A. Cengel, Perelman Center for Advanced Medicine

(United States)

$6 \quad$ Photodynamic Therapy VI

Timothy C. Zhu, The University of Pennsylvania Health System (United States)

7 Photodynamic Therapy VII

Jonathan P. Celli, University of Massachusetts Boston (United States)

8 Photodynamic Therapy VIII

Kimberley S. Samkoe, Geisel School of Medicine (United States) 